\title{
English Learning Process in the Vocational School Based On the Systemic Functional Linguistics (SFL)
}

\author{
Sudar \\ Purworejo Muhammadiyah University \\ rofiqsdr@gmail.com
}

\begin{abstract}
Learning English in modern era needs flexibility and creativity. How to learn English interactively and appropriately with the learners needs is challenging to be investigated. In this study the researcher investigates the process of learning English, particularly in vocational school based on the Systemic Functional Linguistics (SFL). Did the English teachers and their students learn English based on the systemic functional linguistics? Why did they use systemic functional linguistics approach for learning English? The purposes of this study is to investigate the implementation of Systemic Functional Linguistics (SFL) in learning English of vocational schools. This study is qualitative descriptive research development. To collect the data the researcher conducting observation, interview, recording the classroom of English learning process. The results of analyzing the data taken from the field of the research, it is stated that not all English teachers and students of vocational schools implemented Systematic Functional Linguistics (SFL) approach in the learning process. It is caused English teachers and students have not familiar completely the use of English appropriately related to context of situation and context of culture.
\end{abstract}

Key words: English, learning process, vocational Schools, systemic functional linguistic(SFL)

\section{INTRODUCTION}

Teaching learning process in the vocational school should be interested. Learning English in the vocational schools will be meaningful if the teaching learning process match with the students' needs in the future life. Students of vocational schools should be able to communicate in their life of work using English as a mean communication. Lee, Jenny, Wahidiat, Khurniawan,(2017)statedthat communication skill using English in international society is demanded to develop for vocational school students.
Based on the observation conducted in the three of state vocational schools in Purworejo, Central Java, Indonesia.It is found that teaching learning process in the vocational schools did not run well related to the Systemic Functional Linguistics (SFL). It makes the researcher is interested to conduct this research concerning with English texts which is related to the industry's needs. Further, learning English basically should base on the function of the language itself. To break down that issues, the researchers conducted a study in the three state vocational schools as a sample. The three vocational schools are state vocational school one, state vocational school two, and state vocational school tree in Purworejo, central Java Indonesia. This study focuses on the issue of; (1) why the texts of English material are not yet completely based on the Systemic Functional Linguistics (SFL)? (2) How is the English texts based on Systemic Functional Linguistics (SFL) able to increase the students mastery of English language skills? The purposes of this study are as follows; (1) to describe the reasons of why English texts used in vocational schools not yet based on the Systemic Functional Linguistics (SFL)completely?(2)To investigate deeply the development of students' English language skills while they are learning English based on the Systemic Functional Linguistics.

Systemic Functional Linguistics (SFL)

$(S F L)$ is knowledge of language which is rarely investigated in Indonesia. SFL is particularly investigating the use of a language based on context of situation and based on culture. Using a language accurately is very necessary and it is needed in globalization. The researcher discusses this topic intends to describe the use of a language in real society. The researcher assumed that the English book used in vocational school is not related the function of a language as a system. Halliday and Matthienssen. C.M.I.M (2004) said that a language is a concept related to a system to express a meaning. Furthermore, Halliday and Hasan $(1985,1989)$ cited in Flowerdew, (2013) argue that language, context, and text are all aspect of a language in relation to language as a 
social symbol.Language is a system which is necessary understood by all language learners. Further, Thomas and Marriel, (2004:2) stated that in the point of view of SFL, language is a system and meaning. It meant that in the using of a language, meaning is not neglected. Further, the meaning of a language should connect to the context of situation and the context of culture.

Saussure, (1950),J.R,Firt,(1957) Chomsky, 1960), Halliday, (1972), Malinowski (1987) they argued that in the using of a language is not separated from the system of language itself, even the system of each languages is different from each other.Further, the scholars argued that the language used is influenced by society where the language is spoken by people around its society. Malinowski (1987) said that" the rule of individual as a member of society; hence the important interaction between nature and nurture". Based on this statement, the researcher critiques that individual language used is not separated from social factor and culture of the place of the language is spoken.Further, this research intends to investigate the meaning of function from SFL perspective. Simply meaning of the word function is often used for a group of words related to the function of the word itself in the sentences. Thomas and Bloor (2004: 9 said that commonly the word Functionis meaningful based on the context of situation where is the language spoken. From theMetafunctions perspective in the SFL, the language used by human being can be classified as the follows; (1) Language is as a tool to convey meaning, it meant that language is used to express our feeling.2. Language is used to participate in the communication with other people. It meant that language is used to express our attitude, and to make a decision. 3. Language can be used to critique the use of another languages. (Thomas and Bloor, 2004: 10-11). Concerning with the function of a language, it is true that a language is able to complete the human being needs both physically and mentally accurately.

\section{Context of Situation and Context of Culture in using a language.}

. Halliday andHasan, (1989: 45-46) argued that context of situation consisting of three components; they are as follows; a. field of discourse, the topic of discourse in using a language is able to influence the using of language itself,b. tenor of discourse, it meant that the participants who are involved in the discussion. Different participants in the different discourse will create different language,c. mode of discourse, it meant that how is the using of a language among of the participants, for example between the writer and the reader, speaker and listeners.Specifically, Halliday dan Hasan, said that context of situation is the nearest society where the language is used. Halliday dan Hasan, (1989:46) state that there are some components of context of culture in relation with the using of a language. Thus components are specifically concerning with the teachers, the principle, the consultants, supervisors, the department of education itself, and also the teaching learning process and the setting of language learning itself. In the context of culture, the researcher assumed that using English in context Indonesian culture is different from the Using English of native speaker , for example English British and USA English.The researcher argued that the language culture of English spoken by Indonesian people is different from the language culture spoken by native speaker.Eggin, (2004:90-99) explained that how is the use of a language related to the context of situation and context of culture.Egginmentioned that there are three components in relation with using a language; such as field, mode, and tenor. a. field: what the language is being used to talk about.It meant that what is the language talking about? Language can be used to talk about social, politics, economic, culture, education, ideology, further, language can be used to talk to the God, for example in form of praying., $b$. mode: the role of a language is playing in the interaction. It meant how the language is used by speakers. For example; language used in casual conversation, language used trough the phone, language used through email, language used trough radio, TV, and other electronics. Further, it is also the language used in form of literary work, for example; novel, short story, legend, and other literary works. Tenor: the social rule relationships played by interactants. 


\section{Spoken and Written language}

Eggin (2004:92-95) stated that there are some characters of spoken and written a language. Those characters are as follows;

Table 1. Typical situations of Language Use: Eggin, (2004:92).

\begin{tabular}{|c|c|}
\hline Spoken Discourse & Written Discourse \\
\hline 1.Interactive & 1.non-interactive \\
\hline 2.two or more & 2.one participant \\
\hline participants & 3.not-face-to-face \\
\hline 3.face-to-face & 4.on her own \\
\hline 4.in the same place at & 5.not language as \\
\hline thesamettme & action \\
\hline 5.language as an & 6. using language \\
\hline action & to reflect \\
\hline 6.using language to & 7.not spontaneous \\
\hline accomplishsome & 8.planning, \\
\hline task & drafting, and \\
\hline 7.spontaneous & rewriting \\
\hline 8.without rehearsing & 9. not casual \\
\hline what is going to be & 10. formal and special \\
\hline sala & occasions \\
\hline $\begin{array}{ll}9.8 \\
10\end{array}$ & \\
\hline $\begin{array}{l}\text { I0.injormal } \\
\text { everyday }\end{array}$ & \\
\hline
\end{tabular}

Based on the arguments stated by Eggin (2004), it is clear that spoken and written discourse are completely different. Further, Halliday, (1994: 93 97) described there are some differences and some similarities of spoken and written language. The three differences are as follow; a. spoken language has high meaning, b. spoken language and written language used in different context which have different goals, c. spoken language and written language have different effects to the speakers and writers of a language. Further, Halliday, stated that written language is presented some ideas which are synosisable. On the contrary, spoken language is more dynamic.

\section{Formal and non-formal language}

Language can be used formal and informally. Naturally, language used conducted formal and informally, these differences influenced the use of the language itself. Eggin, (2004:101) differentiate the characters of formal and informal language. Those differences are as follows;

Table 2. Typical situations of language use: by Eggin, (2004:101).

\begin{tabular}{|c|c|}
\hline informal & formal \\
\hline $\begin{array}{l}\text { 1. equal power } \\
\text { 2. frequent contact } \\
\text { 3.higheffective } \\
\text { involvement }\end{array}$ & $\begin{array}{l}\text { 1.unequal, } \\
\text { hierarchic power } \\
\text { 2.infrequent, or one- } \\
\text { off contact } \\
\text { 3.lowaffective } \\
\text { involvement }\end{array}$ \\
\hline
\end{tabular}

\section{METHODS}

This research used mix method, it is qualitative and research development.Creswell, (2009:4). Qualitative research is a study to explore and to understand individual phenomena or a group of people in the society. The setting of the research are threestate vocational schools in Purworejo, central Java, Indonesia.

\section{The source of data}

The primer data of this study is the results of interview between the researcher and students, teachers of state vocational schools. The form of the data is a note of interview, the note of observation about the using of English texts in the teaching learning process.

Further, thesecond data isin a form of the results of book analysis which is used by teachers and students.

\section{Technique of collecting data}

Chaedar, (2002:154-156) to take the data the researcher can conduct an interview and observation. In this study, the researcher conducting observation and in-depth-interview.

\section{Technique of analyzing the data}

Miles and Huberman, (1994:18), to analyze the data the researcher can do the following steps; (1) collecting the information by conducting an interview, giving questioners, conducting an observation,(2) reducing the data, this step is to identify which is needed data and which is not needed, (3) presenting the selected data in form of table or description, (4) the conclusion .Further, the researcher conducts synthesize analysis about the using the text book related to Systemic Functional Linguistics (SFL).

\section{RESULTS AND DISCUSSIONS}

The data is collected to answer two questions concerning with the implementation of SFL (Systemic Functional Linguistics) in the teaching learning process of vocational schools. The two questions are as follows; (a) did the English teachers and their students learn English based on the systemic functional linguistics? (b) Why did they use systemic functional linguistics approach for learning English? To answer the first research question, the researchers used the following questioners done by teachers and students. The teacher's answers of questioners are presented in the following figures. 


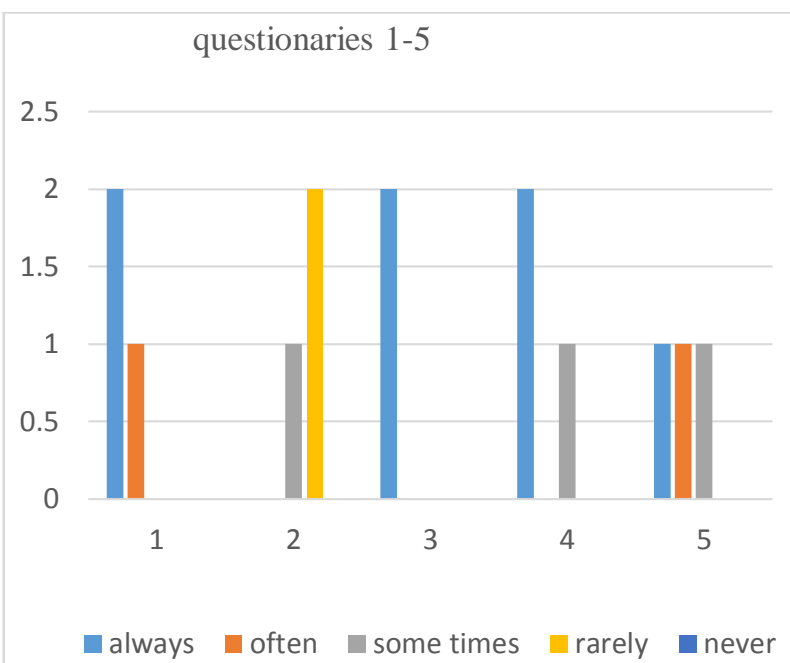

Figure 1. Teaching English material for vocational school based on the syllabus

Thereare twenty five questionaries' concerning to teachers' ideas about the implementation of SFL in the teaching learning process. The $1^{\text {st }}$ questioner is "Teaching English material for vocational school based on the syllabus". Refers to this statement, teachers of vocational school teaching English based on the syllabus. It is reflected in the blue chart in the table, and red color sported that teachers of vocational school often teaching English based on the syllabus. The $2^{\text {nd }}$ questioner is about the material used by English teachers"English materials given to the students taken from the student's book only". Look at the chart, orange chart is in the high level, it reflects that teachers teaching English to their students not only taken from the book, but also taken from different references. The $3^{\text {rd }}$ questioner is "Teaching English material needs variations from different references". Refers tothe chart of this questioner blue chart shows that teachers always make variation material taken from different references. The $4^{\text {th }}$ I teach English texts taken from different resources based on the syllabus". This questioner stated in the chart blue color, it meant that English teachers always taken English material from different references. The $5^{\text {th }}$ Questioner "English materials given to the students related to the student's competency program". The chart number five stated that English teachers some teachers said often, and other English teachers said never did it.

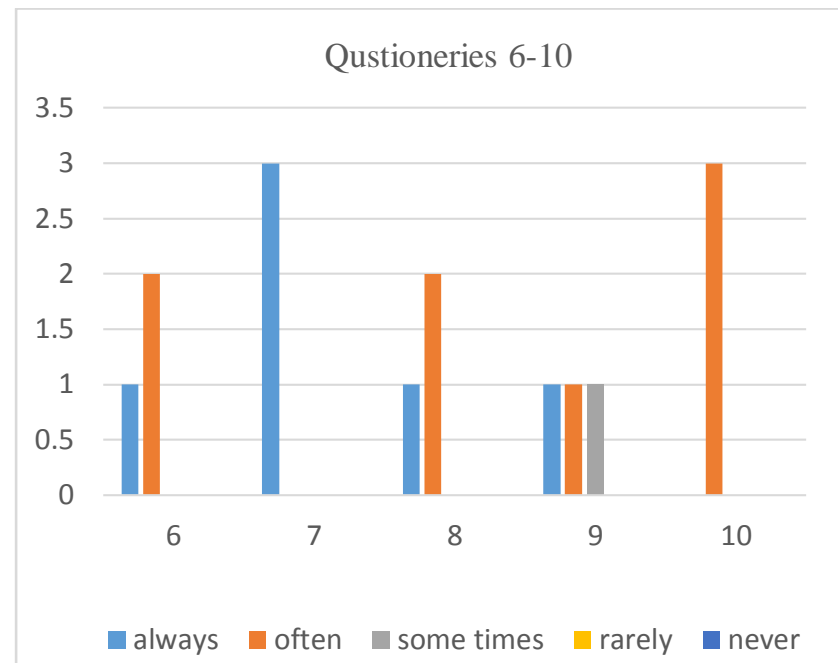

Figure 2. Some of teaching English materials taken from internet

The $6^{\text {th }}$ questioner is about taking English material from internet, the questioner is "Some of teaching English materials taken from internet" .This questioner stated in the chart that English teachers used English material taken from internet is often done by English teachers. The $7^{\text {th }}$ questioner is about the material taken from the internet based on the syllabus. The questioner is "English material taken from internet based on the topics in the syllabus". It is stated in the chart that blue color is dominant. It meant that English teachers used English material taken from internet always connected to the syllabus. The $8^{\text {th }}$ questioner is about the English material taken from students book is suitable with the students' competency. The questioner is "English materials taken from the student's book suitable with the student's competency program". This questioner shows in the chart that English teachers often used English material connected with students' competency. It is performed in the red chart.Questioner number nine is about reading text. The questioner is"Reading texts taken from the students' book are suitable to the students' competency program". It is stated in

The chart that English teachers are rarely using reading English text based on the students competency. It is reflected in the orange chart. The 10th questioner is about teacher's developing English material. The questioner is "English teachers develop English material based on the student's competency program". It is stated in the chart that English teachers often develop English material related to student's competency. It is performed in the orange chart. 


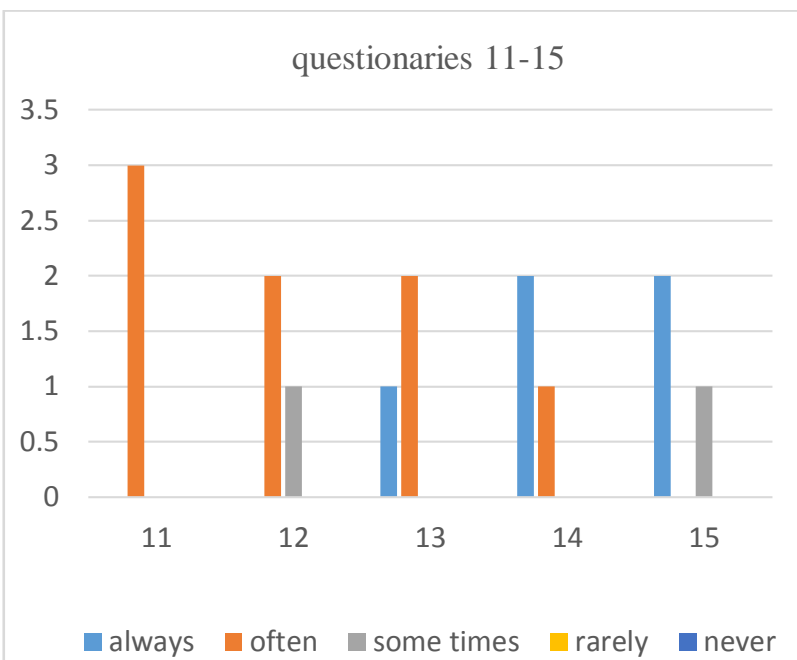

Figure 3. Students understand the English materials although it is not suitable to their competency program

The $11^{\text {th }}$ questioner is about students understanding English material even it is not suitable with the student's competency. The questioner is "Students understand the English materials although it is not suitable to their competency program". The chart shows that students are understood the English material, even it is not suitable with their competency. It is performed in the orange chart. The $12^{\text {th }}$ questioner is about material taken from the internet suitable with student's competency. The questioner is" English texts taken from the internet are suitable to student's competency program". Related to the chart, English teachers are often take the material internet connect to students competency. It showed in the chart color of orange. It is in the high level than other color.The $13^{\text {th }}$ questioner is about the using English material from the internet are able to improve students language skills. The questioneris"English texts taken from internet are able to improve students English language skills".This questioner shows in the chart that orange color is in the high level. It meant that English material taken from the internet is able to improve student's language skills. The $14^{\text {th }}$ questioner is about the combination of material from student's book and English material taken from internet are able to develop student's language skills. The questioner is

"Combining the material from the student's English book and material taken from the internet develop students' English language skills.It shows in the chart that blue color is in the high level, it meant that English material from book and English material from internet can be used to improve student's language skills. The $15^{\text {th }}$ questioner is about the form of English material in form of video related to the syllabus. The questioner is "English texts taken from the internet are in form of video suitable to the topics in the syllabus.

The chart shows that the material in form of video taken from internet is related to the syllabus. It meant that English material taken from internet in form video similar to the material in the syllabus.

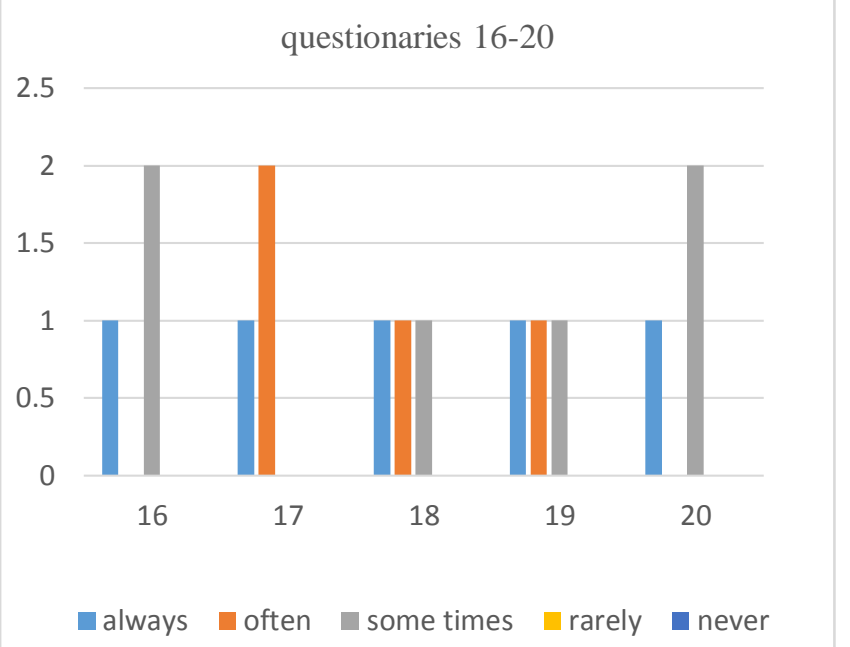

Figure 4. English texts taken from the internet are in form of dialogue

The $16^{\text {th }}$ questioner is about the English material taken from internet is in form of dialogue.

The questioner is "English texts taken from the internet are in form of dialogue. The chart shows that English material taken from the internet is never in form of dialogue. It is stated in the color of grey in high level. The $17^{\text {th }}$ questioner is the material from internet is in form of short conversation. The questioner is "English texts taken from the internet are form of short conversation.In the chart it is showed that the orange color is in the high level, it meant that the material of English taken from internet is often in form of short conversation. The $18^{\text {th }}$ questioner is about the form of English material in the form of monologue. The questioner is "English texts taken from the internet are in form of monologue. It shows in the chart that material in form of monologue is some time used by teachers. The questioner $19^{\text {th }}$ is about in form of story. The questioner is "English texts taken from the internet are in form of a story". It is performed in the chart, that English material taken from internet rarely in form of a story. The $20^{\text {th }}$ questioner is about the English material taken from internet in from of a simple text. The questioner is "English texts taken from the internet are in form of a simple text.The chart shows that the English teachers never used the English material in form of a story. 


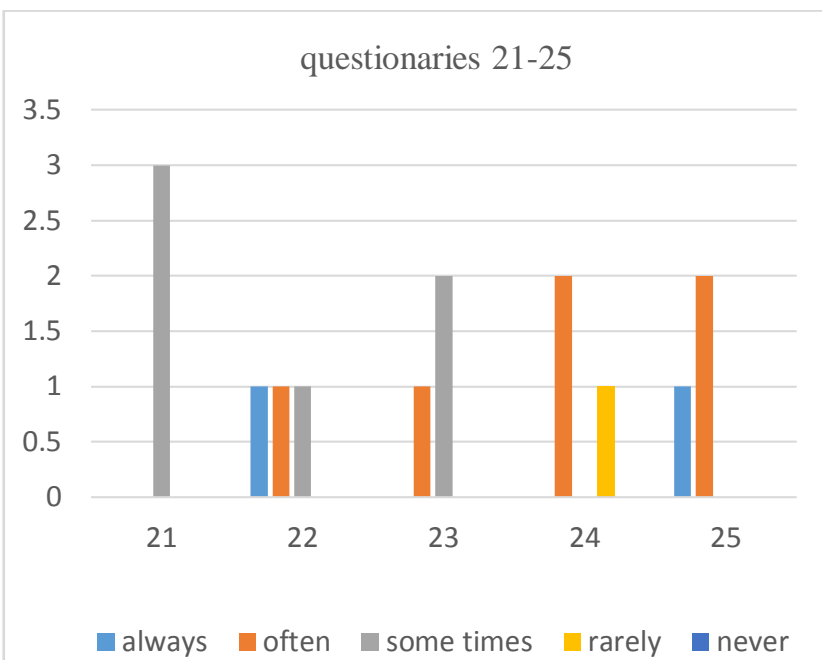

Figure 5 English texts taken from the internet are in form of a brochure

The questioner $21^{\text {th }}$ is about English material in form of brochure. The questioner is "English texts taken from the internet are in form of a brochure". The chart shows that English teachers are never used English material in form of brochure. It reflected in the form of grey color in high level. The $\mathbf{2 2}^{\text {th }}$ questioner is about the English material provided by teachers. The questioner is "English texts taken from the internet are provided by teachers. The chart shows that English material taken from internet is always provided by teachers. It is reflected in the blue color. The $23^{\text {th }}$ questioner is about using the English material taken from internet searched by students. The questioner is "English texts taken from the internet are searched by students". It shows in the chart that sometimes searched by students. It is in grey color more dominant than others. The questioner $24^{\text {th }}$ is about using English material from students' book monotonously. The questioner is "English texts taken from the student's book are monotonous. It is reflected that the orange color chart in high level. It meant that the English material from student's book is monotonously. The $25^{\text {th }}$ questioner is about the texts used in the students book are common texts. The questioner is "English texts taken from the student's book are general texts. It shows in the chart that the red color is in the high level. It meant that English texts from the student's book are general texts.

\section{Students' respond to the $S F L$ in the Classroom}

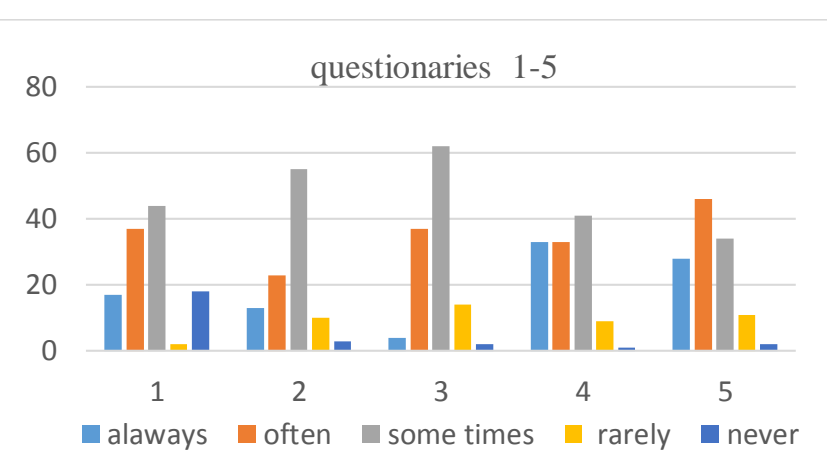

Figure 6. Study English cheerfully

There are also twenty five questionaries' related to the students' respond to the implementation of SFL in the classroom. The following are the questionnaires; $1^{\text {st }}$ questionaries' is about student feeling when they were learning English in the classroom. The questionnaires is"I study English cheerfully". The dominant chart about students feeling when they were learning English is grey color. It meant that sometimes students enjoy to learn English. Some students said that they often enjoy their learning English. Further, more less than $17 \%$ students of vocational schools enjoy learning English. The $2^{\text {nd }}$ questioner is about student's vocational school's competency, it mean that whether they study English related to the competency or not. The questioner is" I study English related to my competency". Related this questioner, $55 \%$ students of vocational school sometimes learning English related to their competency. It is only $21 \%$ students learn English suitable with their competency. It is reflected in the orange chart. Further, 11\% students learn English always related to their competency. The $3^{\text {rd }}$ questioner is aboutlearning English related to student's motivation. The questioner is "I learn English material related to my motivation". There is $61 \%$ students of vocational schools sometimes learn English material able to encourage their motivation to learn English. Further, there is $39 \%$ students of vocational school are often learn English to be able to encourage their motivation. Then, there is $0,2 \%$ students of vocational school always learning English and it is motivated them to learn better. The $4^{\text {th }}$ questioner is about English material which is learned by students, whether the material is interested for them or not. The questioner is "English materials are interested for me" .There is $31 \%$ students of vocational schools are often and always interested to the English material given by their teachers. Further, $40 \%$ students of vocational schools sometimes interested to the English material that they learned. 
The $5^{\text {th }}$ questioner is about the English material is encouraged students to learn English or not. The questioner is "English texts encourages me to learn English". There is 45\% students said that the English material they learned are often able to encourage them to learn English. Then, there is $32 \%$ students of vocational school said that sometime the English material are able to encourage them to learn English. Further, there is $28 \%$ students stated that the English material are able to encourage them to learn English.

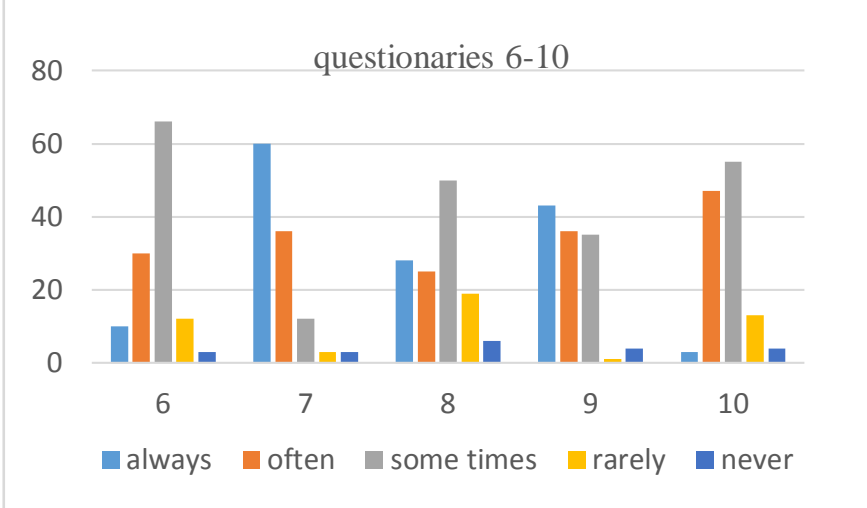

Figure 7. Learned all the English texts related to my competency that I choose

The $6^{\text {th }}$ questioner is about whether the English texts are suitable with their competency or not. The questioner is "I learned all the English texts related to my competency that I choose". There $68 \%$ students said that sometimes the English texts

Related to their competency. 30\% students answer that they often learn English text related to their competency. Then, $10 \%$ students said that they always learn English text related to their competency. The $7^{\text {th }}$ questioner is about whether the English texts given by teachers are related to the syllabus or not, the questioner is "All the topics of English texts given by teachers suitable to the syllabus". Concerning to the chart, blue chat is in the highest level, it meant that $60 \%$ students said that all the English texts given by teachers always based on the syllabus. Further, $38 \%$ students said that all the English texts are often based on the syllabus. The $8^{\text {th }}$ questioner is about all the English text taken from student's book whether suitable with student's competency or not. The questioner is "All the topics of English texts taken from the student's book are related to my competency". There is 50\% students said that sometimes English texts taken from students book related to their competency. Then, 27\% students stated that they always learned English texts related to their competency, and there is $24 \%$ students mentioned that theyoften learned English text related to their competency. The $9^{\text {th }}$ questioner is about English texts used by teachers, whether the English texts based on the syllabus or not. The questioner is "Englishteachers teach English texts based on the topics in the syllabus". Referring to the chart, 43\% students said that English teachers teach English based on the topics taken from syllabus. They said always based on the topics in the syllabus. 35\% students said always used the topics taken from the syllabus, then $34 \%$ students said sometimes used topic in the syllabus. The $10^{\text {th }}$ questioner is about students understanding the English texts given by English teachers. The question is "I understand well all the all the English texts given by English teachers".

The chart of students "understanding the English texts given by teachers, it is stated that 55\% students rarely understand the material given by teachers. Further, $45 \%$ students said that they often understand the English text given by teachers.

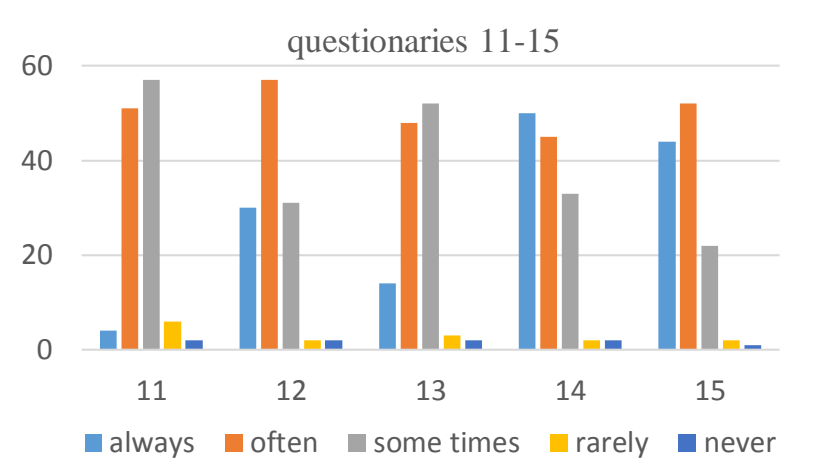

Figure 8. Understand English texts given by teachers taken from the internet

The $11^{\text {th }}$ questioner answer by students is about students understanding English texts taken from internet. The questioner is "I understand English texts given by teachers taken from the internet". There is 58\% students said that they are sometimes understand the English texts taken from internet. often understand English texts from internet. The $12^{\text {th }}$ questioner is about whether the English text taken from the internet suitable with syllabus or not. The questioner is "English texts taken from internet is suitable with the topic in the syllabus". 58\% students said that the English texts taken from internet is suitable with the syllabus. Further, there is 30\% saidthat they are sometimes and some of them always understand the English text taken from internet. The $13^{\text {th }}$ is about whether the material taken from internet is suitable with the student's competency or not. The questioner is "English teachers teach the English text taken from the internet suitable with my competency.

There is $52 \%$ students sometimes said that English texts taken from internet are suitable with the 
students competency. Then, there is $48 \%$ students often understand the English texts taken from internet. The $14^{\text {th }}$ questioner is about students learning activity, whether students learned the English texts from students book completely or not. The questioner is "English texts taken from the student's book learned by students completely. There is $50 \%$ students said that they always learned English texts completely. There is 48\% students said that they often learned English completely. The questioner $15^{\text {th }}$ is about English teacher used English text from internet as supplementary or as main reference. The questioner is "English teachers used English Texts taken from internet as supplementary".There is $52 \%$ students said that always as supplementary English text. Further, there is $48 \%$ students often used English text from internet as supplementary.

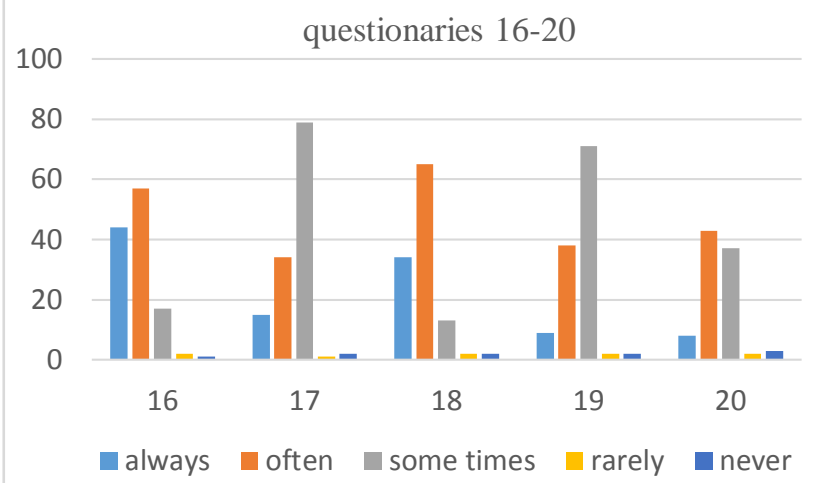

Figure 9. learn English texts taken from internet based on the syllabus

The $16^{\text {th }}$ questioner is about English texts from internet, weather it is suitable to the syllabus or not. The questioner is "I learn English texts taken from internet based on the syllabus". There is 57\% students said that they learn English texts taken from internet connected to the syllabus. Then there is $43 \%$ students agree that they learn English texts taken from internet related to the syllabus.

The $17^{\text {th }}$ questioner is about whether the English texts taken from internet suitable with students competency or not. The questioner is "English texts taken from internet are related to students competency". There is $78 \%$ students said sometimes the English texts taken from internet related to the students' competency. Then, there is $22 \%$ students said that English texts taken from internet often related to the students competency. The $18^{\text {th }}$ questioner is about teachers to develop English texts related to the syllabus. The questioner is" English teachers develop English texts based on the syllabus". There is $65 \%$ students said that the English material developed by teachers are based on the syllabus. Further, there is $35 \%$ students said that English texts developed by teachers are always based on the syllabus. The $19^{\text {th }}$ questioner is about the topics in the syllabus are related to the students competency. The questioner is "English texts written in the syllabus are related to the students competence". According to the chart, there is $70 \%$ students said that sometimes the English texts concerned with the students competence. Then, there is $30 \%$ student said the English texts written in the topic always related to the students competency. The $20^{\text {th }}$ questioner is about English texts written in the student's book whether related to the student's competency or not. The questioner is "English texts written in the texts books are related to the student's competency". There is 45\% students said that English texts written in the students book often based on the students competency. Further, there is 35\% students said that sometimes the English texts written in the students book are related to the students competency.

\section{CONCLUSIONS}

Based on the discussion on the implementation of SFL in the teaching learning process, whether from teachers and students perceptive, it is written down that teaching learning process in the vocational school mostly concerned with the systemic functional linguistics. It meant that the students and teachers used English language related to the context of situation and context of culture.

\section{Short Bio Data}

Sudar is the Doctor of English Education. His major study is in applied linguistics. He took Doctoral Degree in English Education Program, Semarang State University (UNNES) 2010-2014. His research focuses on Critical Discourse Analysis, Applied Linguistics, and Linguistics Analysis. He is the senior lecturer in English Education Program of Purworejo Muhammadiyah University.

\section{References}

Alwasih, Chaedar. (2002). Pokoknya Kualitatif. Bandung: Pustaka Jaya.

Bloor, Thomas and Meriel. 2004. The Functional Analysis of English. UK: Arnold.

Creswell, John W. (2009). Research Design: Qualitative, Quantitative and Mixed Methods Approaches. California: Sage Publication Inc.

Eggin, S. 2004. An Introduction to Systemic Functional Linguistics. UK: London:Continuum..

Flowerdrew, John 2013. Discourse in English Language Education. USA and Canada: Routledge. New York. 
Halliday, M.A.K. \& Matthienssen. C.M.I.M. 2004. An Introduction to Functional Grammar. London; Edward Arnold.

Halliday, M.A.K., and R. Hasan. 1985. Language, Context, and Text. Melbourne: Deakin University Press. (Republished by OUP, 1989).

Halliday, 1994. Spoken and Written Language. Victoria: Deakin University.

Huberman and Miles. 1994. Qualitative Data Aanlysis Second edition. London: Sage Publications.

Lee, jenny, Wahidiat, Khurniawan, 2017.

The implement of strategy to

RevitalizeVocational School trough

Ecosystem Bilingual Learning.

Directorat of Vocational School

Affair. Ministry of Education and

Culture.Jakarta, Indonesia. 